\title{
PHYTOPHTHORA CACTORUM (LEBERT \& COHN) J. SCHRÖT AS CAUSAL AGENT OF DIEBACK OF CHESTNUT AND APPLE TREES IN MACEDONIA ${ }^{\#}$
}

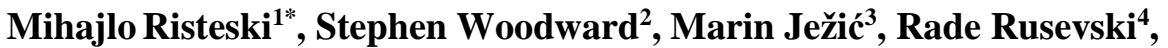 \\ Biljana Kuzmanovska ${ }^{4}$, Kiril Sotirovski ${ }^{1}$
}

\author{
${ }^{1}$ Faculty of Forestry, Ss. Cyril and Methodius University, Skopje, Republic of Macedonia \\ ${ }^{2}$ The Institute of Biological and Environmental Sciences, University of Aberdeen, Scotland \\ ${ }^{3}$ Faculty of Science, University of Zagreb, Croatia \\ ${ }^{4}$ Faculty of Agricultural Sciences and Food, Ss. Cyril and Methodius University, \\ Skopje, Republic of Macedonia \\ *e-mail: mihajlo.risteski@gmail.com
}

From 2013-2017, 11 chestnut populations and 16 apple orchards/plantations in Macedonia were examined for health; soil, root and bark samples were collected from trees expressing symptoms regarded as Phytophthora specific. Using leaf baits of Prunus laurocerasus and selective V8 Agar (PARPNH), 19 pure Phytophthora sp. cultures were isolated and identified as $P$. cactorum by ITS sequencing. Sixteen isolates were from apple trees and 3 from chestnut trees. Phylogenetic analyses suggested slight distance between $P$. cactorum isolates originating from chestnut trees compared to those from apple orchards. Assessment of pathogenicity using chestnuts twigs showed no differences between $P$. cactorum isolates from the two tree host species.

Key words: Malus spp.; Castanea sativa; pathogenicity; phylogenetic analysis

\section{INTRODUCTION}

The genus Phytophthora was first reported in 1845, when Botrytis infestans, fully described in 1876 as Phytophthora infestans (Mont) De Bary was identified as the causal agent of potato blight, the main factor causing yield losses during the infamous Great Irish Famine (1844-1886). The disease was responsible for the death of approximately 1-1.5 million people and sparked massive emigration from Ireland because of the lack of food available to ordinary people [1]. Soon after these events, in 1870 Peronospora cactorum (Levert and Cohn) J. Schröt was first described as the cause of rot on the cacti Cereus giganteus and Melocactus nigrotomentosus in the Czech Republic (Lebert and Cohn, 1870, cited in [2]). This fungus-like organism (FLO) was later transferred to the genus Phytophthora.

Phytophthora cactorum is a generalist plant pathogen with a worldwide distribution. It causes a variety of symptoms on many plant hosts: dampingoff of seedlings, fruit rot, leaf and stem rot, collar and crown rot, stem canker and root rot [3]. Numerous plant diseases have been attributed to this oomycete, and it has been recorded on over 200 plant species, causing disease on 150 genera (e.g. including Fagus spp., Juglans regia, Malus, Castanea sativa), in 60 plant families (Tucker, 1993; Nienhous, 1960; cited in [2]). P. cactorum causes necrosis on inoculated plants of Quercus robur [4], on apple, rhododendron and strawberry, with genetically different isolates expressing different host specificity [5], and is also one of the Phytophthora spp. complex responsible for ink disease of chestnut trees [6]. The only accessible relevant data on Phytophthora species detected in Macedonia is the paper published by the European and Mediterranean Plant Protection Organization (EPPO) for presence of dying off symptoms caused by $P$. cryptogea, dating from 1985 [7]. 
The morphological characteristics used for detection of Phytophthora spp., such as dimensions and shapes of zoosporangia and oogonia, may be highly variable and often overlap between species, making identification to the species level difficult $[8,9]$. Leonian [10] stated that $P$. cactorum is a species easily identified by morphological characteristics, while later, isozyme analysis and mtDNA studies showed a high level of similarity between isolates originating from different geographical locations $[11,12]$.

In the last 15-20 years there has been an increase in the number of newly described Phytophthora species [13-16], but keys available for morphological identification are not in accord with the natural division to species level sensu stricto [17]. Molecular methods applied to Phytophthora species isolates, therefore, are a necessary tool for accurate identification to the species level.

In this study, we assessed chestnut populations and apple orchards in the Republic of Macedonia for symptoms of Phytophthora sp. infections.
Bark and roots from symptomatic trees, plus samples of surrounding soils were collected for isolation of Phytophthora spp. and the pathogenicity of $P$. cactorum strains isolated during the study was assessed.

\section{MATERIALS AND METHODS}

Collection of samples. Between 2013 and 2017, we assessed 27 sites for presence of symptoms on apple and chestnut trees (Table 1). Soil samples were collected from four sides of symptomatic trees after removal of the soil surface organic layer using methods described previously [18-20]. The four soil samples from a single tree, each from a pit of ca $25 \times 25 \times 25 \mathrm{~cm}$, were mixed in sterile plastic bags, and stored at room temperature $\left(24^{\circ} \mathrm{C}\right.$ $\pm 4{ }^{\circ} \mathrm{C}$ ) until processed. Bark samples, taken from trunk lesions and rotten tissue (mostly from the collar area), or root fragments, were collected using a knife or axe previously surface sterilized in $70 \%$ ethanol.

Table 1. List of sites assessed for presence of disease symptoms characteristic for Phytophthora infection

\begin{tabular}{|c|c|c|c|c|c|c|}
\hline $\mathbf{N}_{0}$ & Site & $\begin{array}{l}\text { GPS coordi- } \\
\text { nates }\end{array}$ & $\begin{array}{l}\text { Host } \\
\text { age }\end{array}$ & $\begin{array}{l}\text { Collected } \\
\text { material }\end{array}$ & $\begin{array}{l}\text { Symptomatic } \\
\text { (S) / } \\
\text { asymptomatic } \\
\text { (A) }\end{array}$ & $\begin{array}{c}\text { Type of soil } \\
{[37]}\end{array}$ \\
\hline 1 & $\begin{array}{l}\text { „Agroplod“ } \\
\text { Resen } \\
\text { Apple orchard }\end{array}$ & $\begin{array}{l}\text { Lat: } 41.090597 \\
\text { Lon: } 21.019831\end{array}$ & $\begin{array}{c}\text { Malus } \\
\text { domestica } \\
\sim 15\end{array}$ & $\begin{array}{c}\text { Soil } \\
\text { Roots }\end{array}$ & $S$ & Fluvisol \\
\hline 2 & $\begin{array}{l}\text { v. Perovo Resen } \\
\text { Apple orchard }\end{array}$ & $\begin{array}{l}\text { Lat: } 41.016807 \\
\text { Lon: } 20.990369\end{array}$ & $\begin{array}{l}\text { Malus do- } \\
\text { mestica } \\
\quad \sim 15\end{array}$ & $\begin{array}{l}\text { Soil } \\
\text { Roots } \\
\text { Bark }\end{array}$ & $S$ & Gleysol \\
\hline 3 & $\begin{array}{l}\text { v. Gorna Bela Crkva } \\
\text { Resen } \\
\text { Apple orchard }\end{array}$ & $\begin{array}{l}\text { Lat: } 41.051997 \\
\text { Lon: } 21.021626\end{array}$ & $\begin{array}{l}\text { Malus do- } \\
\text { mestica } \\
\quad \sim 10\end{array}$ & $\begin{array}{l}\text { Soil } \\
\text { Roots } \\
\text { Bark }\end{array}$ & $S$ & Fluvisol \\
\hline 4 & $\begin{array}{l}\text { v. Grncari Resen } \\
\text { Apple orchard }\end{array}$ & $\begin{array}{l}\text { Lat: } 41.010382 \\
\text { Lon: } 21.052023\end{array}$ & $\begin{array}{l}\text { Malus do- } \\
\text { mestica } \\
\quad \sim 15\end{array}$ & $\begin{array}{l}\text { Soil } \\
\text { Roots } \\
\text { Bark }\end{array}$ & $\mathrm{S}$ & Fluvisol \\
\hline 5 & $\begin{array}{l}\text { v. Brajcino Resen } \\
\text { Apple orchard }\end{array}$ & $\begin{array}{l}\text { Lat: } 40.898478 \\
\text { Lon: } 21.152175\end{array}$ & $\begin{array}{l}\text { Malus do- } \\
\text { mestica } \\
\quad \sim 15\end{array}$ & $\begin{array}{c}\text { Soil } \\
\text { Roots } \\
\text { Bark }\end{array}$ & $S$ & Fluvisol \\
\hline 6 & $\begin{array}{l}\text { v. Carev Dvor } \\
\text { Resen } \\
\text { Apple orchard }\end{array}$ & $\begin{array}{l}\text { Lat: } 41.036188 \\
\text { Lon: } 21.004805\end{array}$ & $\begin{array}{l}\text { Malus do- } \\
\text { mestica } \\
\quad \sim 15\end{array}$ & $\begin{array}{l}\text { Soil } \\
\text { Roots } \\
\text { Bark }\end{array}$ & $\mathrm{S}$ & Fluvisol \\
\hline 7 & $\begin{array}{l}\text { v. Ezerani } \\
\text { Resen } \\
\text { Apple orchard }\end{array}$ & $\begin{array}{l}\text { Lat: } 41.024585 \\
\text { Lon: } 21.025962\end{array}$ & $\begin{array}{l}\text { Malus do- } \\
\text { mestica } \\
\quad \sim 15\end{array}$ & $\begin{array}{l}\text { Soil } \\
\text { Roots } \\
\text { Bark }\end{array}$ & $\mathrm{S}$ & Fluvisol \\
\hline 8 & $\begin{array}{l}\text { v. Pretor } \\
\text { Resen } \\
\text { Apple orchard }\end{array}$ & $\begin{array}{l}\text { Lat: } 40.988544 \\
\text { Lon: } 21.055793\end{array}$ & $\begin{array}{l}\text { Malus do- } \\
\text { mestica } \\
\quad \sim 15\end{array}$ & $\begin{array}{l}\text { Soil } \\
\text { Roots } \\
\text { Bark }\end{array}$ & $S$ & Fluvisol \\
\hline 9 & $\begin{array}{l}\text { v. Stenkovec } \\
\text { Resen } \\
\text { Apple orchard }\end{array}$ & $\begin{array}{l}\text { Lat: } 41.55523 \\
\text { Lon: } 20.613661\end{array}$ & $\begin{array}{l}\text { Malus do- } \\
\text { mestica } \\
\quad \sim 15\end{array}$ & $\begin{array}{l}\text { Soil } \\
\text { Roots } \\
\text { Bark }\end{array}$ & $\mathrm{S}$ & $\begin{array}{c}\text { Dystric } \\
\text { Cambisol }\end{array}$ \\
\hline
\end{tabular}


Table 1 (continuation)

\begin{tabular}{|c|c|c|c|c|c|c|}
\hline 10 & $\begin{array}{l}\text { v. Gradsko } \\
\text { Gradsko } \\
\text { Apple orchard }\end{array}$ & I & $\begin{array}{c}\text { Malus } \\
\text { domestica } \\
\quad \sim 5\end{array}$ & $\begin{array}{l}\text { Soil } \\
\text { Roots } \\
\text { Bark }\end{array}$ & $S$ & $\begin{array}{c}\text { Humic Calcaric } \\
\text { Regosol + Regosol }\end{array}$ \\
\hline 11 & $\begin{array}{l}\text { v. Sopotsko } \\
\text { Resen } \\
\text { Apple orchard }\end{array}$ & I & $\begin{array}{c}\text { Malus } \\
\text { domestica } \\
\sim 15\end{array}$ & $\begin{array}{l}\text { Soil } \\
\text { Roots } \\
\text { Bark }\end{array}$ & S & I \\
\hline 12 & $\begin{array}{l}\text { v. Jankovec } \\
\text { Resen } \\
\text { Apple orchard }\end{array}$ & I & $\begin{array}{c}\text { Malus } \\
\text { domestica } \\
\sim 15\end{array}$ & $\begin{array}{l}\text { Soil } \\
\text { Roots } \\
\text { Bark }\end{array}$ & $S$ & I \\
\hline 13 & $\begin{array}{l}\text { v. Bolno } \\
\text { Resen } \\
\text { Apple orchard }\end{array}$ & / & $\begin{array}{c}\text { Malus } \\
\text { domestica } \\
\text { / }\end{array}$ & $\begin{array}{l}\text { Soil } \\
\text { Roots } \\
\text { Bark }\end{array}$ & $S$ & l \\
\hline 14 & $\begin{array}{l}\text { v. Gorno Dupeni } \\
\text { Resen } \\
\text { Apple orchard }\end{array}$ & I & $\begin{array}{c}\text { Malus } \\
\text { domestica } \\
\sim 15\end{array}$ & $\begin{array}{l}\text { Soil } \\
\text { Roots } \\
\text { Bark }\end{array}$ & $S$ & I \\
\hline 15 & $\begin{array}{l}\text { v. Dolna Bela Crkva } \\
\text { Resen } \\
\text { Apple orchard }\end{array}$ & l & $\begin{array}{c}\text { Malus } \\
\text { domestica } \\
\sim 15\end{array}$ & $\begin{array}{l}\text { Soil } \\
\text { Roots } \\
\text { Bark }\end{array}$ & $S$ & l \\
\hline 16 & $\begin{array}{l}\text { v. Mislesevo } \\
\text { Struga } \\
\text { Apple orchard }\end{array}$ & $\begin{array}{l}\text { Lon: } 41.178572 \\
\text { Lat: } 20.705224\end{array}$ & $\begin{array}{l}\text { Malus sp. } \\
\quad \sim 10\end{array}$ & $\begin{array}{l}\text { Soil } \\
\text { Roots }\end{array}$ & $\mathrm{S}$ & Fluvisol \\
\hline 17 & $\begin{array}{l}\text { v. Skudrinje } \\
\text { Debar }\end{array}$ & $\begin{array}{l}\text { Lon: } 41.559646 \\
\text { Lat: } 20.602625\end{array}$ & $\begin{array}{l}\text { Castanea } \\
\text { sativa } \\
\sim 50\end{array}$ & $\begin{array}{l}\text { Soil } \\
\text { Roots }\end{array}$ & $S$ & Rendzic Leptosol \\
\hline 18 & $\begin{array}{l}\text { v. Osoj } \\
\text { Kicevo }\end{array}$ & $\begin{array}{l}\text { Lon: } 41.530615 \\
\text { Lat: } 20.934237\end{array}$ & $\begin{array}{l}\text { Castanea } \\
\text { sativa }\end{array}$ & $\begin{array}{c}\text { Soil } \\
\text { Roots }\end{array}$ & $\mathrm{S}$ & Rendzic Leptosol \\
\hline 19 & $\begin{array}{l}\text { v. Kaliste } \\
\text { Struga }\end{array}$ & $\begin{array}{l}\text { Lon: } 41.166303 \\
\text { Lat: } 20.650994\end{array}$ & $\begin{array}{l}\text { Castanea } \\
\text { sativa } \\
\sim 60\end{array}$ & $\begin{array}{c}\text { Soil } \\
\text { Roots }\end{array}$ & $S$ & Rendzic Leptosol \\
\hline 20 & $\begin{array}{l}\text { v. Recane } \\
\text { Gostivar }\end{array}$ & $\begin{array}{l}\text { Lon: } 41.745676 \\
\text { Lat: } 20.825748\end{array}$ & $\begin{array}{l}\text { Castanea } \\
\text { sativa } \\
/\end{array}$ & $\begin{array}{l}\text { Soil } \\
\text { Roots }\end{array}$ & $S$ & Cambisol \\
\hline 21 & $\begin{array}{l}\text { v. Kale } \\
\text { Tetovo }\end{array}$ & $\begin{array}{l}\text { Lon: } 42.019510 \\
\text { Lat: } 20.958687\end{array}$ & $\begin{array}{l}\text { Castanea } \\
\text { sativa } \\
\sim 15 \\
\end{array}$ & $\begin{array}{l}\text { Soil } \\
\text { Roots }\end{array}$ & $S$ & Cambisol \\
\hline 22 & $\begin{array}{l}\text { v. Vrutok } \\
\text { Gostivar }\end{array}$ & $\begin{array}{l}\text { Lon: } 41.763703 \\
\text { Lat: } 20.825986\end{array}$ & $\begin{array}{l}\text { Castanea } \\
\text { sativa } \\
\sim 50 \\
\end{array}$ & $\begin{array}{l}\text { Soil } \\
\text { Roots }\end{array}$ & $\mathrm{S}$ & Cambisol \\
\hline 23 & $\begin{array}{l}\text { v. Trebenista } \\
\text { Ohrid }\end{array}$ & $\begin{array}{l}\text { Lon: } 41.196587 \\
\text { Lat: } 20.772027\end{array}$ & $\begin{array}{l}\text { Castanea } \\
\text { sativa } \\
\sim 50\end{array}$ & $\begin{array}{l}\text { Soil } \\
\text { Roots }\end{array}$ & $S$ & $\begin{array}{l}\text { Rendzic Leptosol } \\
\text { and Chromic } \\
\text { Leptic Luvisol on } \\
\text { hard limestones }\end{array}$ \\
\hline 24 & $\begin{array}{l}\text { a. "Strazha" } \\
\text { Kicevo }\end{array}$ & $\begin{array}{l}\text { Lon: } 41.695773 \\
\text { Lat: } 20.844772\end{array}$ & $\begin{array}{l}\text { Castanea } \\
\text { sativa } \\
\sim 40\end{array}$ & $\begin{array}{l}\text { Soil } \\
\text { Roots }\end{array}$ & $S$ & $\begin{array}{c}\text { Chromic Leptic } \\
\text { Luvisol on hard } \\
\text { limestones }\end{array}$ \\
\hline 25 & $\begin{array}{l}\text { v. Knezino } \\
\text { Kicevo }\end{array}$ & $\begin{array}{l}\text { Lon: } 41.517146 \\
\text { Lat: } 20.919102\end{array}$ & $\begin{array}{c}\text { Quercus } \\
\text { pubescens } \\
\sim 30\end{array}$ & $\begin{array}{l}\text { Soil } \\
\text { Roots }\end{array}$ & $\mathrm{S}$ & $\begin{array}{l}\text { Chromic Luvisol } \\
\text { on saprolite }\end{array}$ \\
\hline 26 & $\begin{array}{l}\text { v. Smolari } \\
\text { Strumica }\end{array}$ & $\begin{array}{l}\text { Lon: } 41.370692 \\
\text { Lat: } 22.902385\end{array}$ & $\begin{array}{l}\text { Castanea } \\
\text { sativa } \\
\sim 40\end{array}$ & $\begin{array}{l}\text { Soil } \\
\text { Roots }\end{array}$ & $\mathrm{S}$ & Cambisol \\
\hline 27 & $\begin{array}{l}\text { v. Vratnica } \\
\text { Tetovo }\end{array}$ & $\begin{array}{l}\text { Lon: } 42.145672 \\
\text { Lat: } 21.113922\end{array}$ & $\begin{array}{c}\text { Castanea } \\
\text { sativa } \\
\sim 60\end{array}$ & $\begin{array}{l}\text { Soil } \\
\text { Roots }\end{array}$ & $\mathrm{S}$ & $\begin{array}{l}\text { Cambisol + Um- } \\
\text { brisol }\end{array}$ \\
\hline
\end{tabular}


Isolations. The baiting method was applied to all soil and bark samples, using fully open young plant leaves of Prunus laurocerasus as bait. Soil, 250-300 g per sample, with root fragments, was placed in plastic containers and flooded with sterile distilled water, to a depth of approx. $1 \mathrm{~cm}$ above the soil level, and bait leaves floated on the water surface. Containers were incubated in the dark at room temperature $\left(24{ }^{\circ} \mathrm{C} \pm 4{ }^{\circ} \mathrm{C}\right)$ and leaves observed daily for discolored lesions. When observed, small fragments $\left(10-20 \mathrm{~mm}^{2}\right)$ were cut from the lesions and placed on selective PARPNH V8 agar $(200 \mathrm{ml}$ V8 juice/l, pimaricin $10 \mathrm{mg} / \mathrm{l}$, ampicillin $200 \mathrm{mg} / \mathrm{l}$, rifampicin $10 \mathrm{mg} / \mathrm{l}$, pentachloronitrobenzene (PCNB) $25 \mathrm{mg} / \mathrm{l}$, nystatin $50 \mathrm{mg} / \mathrm{l}$ and hymexazol $50 \mathrm{mg} / \mathrm{l}$ ) described in Jung et al. [4], and incubated at room temperature in the dark. Cultures with morphology similar to Phytophthora were sub-cultured to fresh PDA, V8 agar or malt extract agar (MEA).

Morphological identification. Morphological characteristics of isolates were recorded after two weeks of growth in the dark on PDA, V8 agar or MEA, at room temperature $\left(24{ }^{\circ} \mathrm{C} \pm 4{ }^{\circ} \mathrm{C}\right)$. To induce production of sexual and vegetative fruiting bodies, plugs (ca. $1 \mathrm{~cm}^{2}$ ) of young cultures were placed in non-sterile soil extract solution (NSSES) [2]. After 24 hours in NSSES, plugs were washed in sterile distilled water and observed under microscope [20]. Morphological structures were measured, and the identification key of Erwin \& Ribeiro [2] used to identify isolates based on morphology. All structures were photographed.

Growth rate. All isolates were subjected to growth-rate trials according to the protocol described in [21]. Agar plugs $\left(2 \mathrm{~mm}^{2}\right)$ were subcultured from culture margins to Petri plates containing ca. $20 \mathrm{ml} \mathrm{V8}$ agar amended with $0.2 \% \mathrm{Ca}$ $\mathrm{CO}_{3}$ with 4 replicates per sample and incubated at $24^{\circ} \mathrm{C} \pm 4^{\circ} \mathrm{C}$. Growth was measured in 2 perpendicular directions after 6 days of incubation.

DNA isolation and amplification. DNA was isolated from cultures grown in the dark on PDA at room temperature $\left(24{ }^{\circ} \mathrm{C} \pm 4{ }^{\circ} \mathrm{C}\right)$. Surface mycelium was gently collected with a spatula, lyophilized and ground. DNA was extracted from 50-100 $\mathrm{mg}$ of lyophilized tissue per sample, using the Plant-fungi DNA isolation kit (PureLink ${ }^{\mathrm{TM}}$ Plant, Total DNA Purification Kit) following the manufacturers' in- structions. Extracted DNA was subject to PCR using ITS 4 [22] and ITS 6 [23] universal Phytophthora primers, with the following amplification conditions: initial denaturation at $95{ }^{\circ} \mathrm{C}$ for 3 min.; 35 cycles of denaturation $\left(95^{\circ} \mathrm{C}\right.$ for $30 \mathrm{sec}$.), annealing $\left(55{ }^{\circ} \mathrm{C}\right.$ for $30 \mathrm{sec}$.), and extension $\left(72{ }^{\circ} \mathrm{C}\right.$ for 50 sec.); and a final extension at $72{ }^{\circ} \mathrm{C}$ for 10 minutes. Amplicons were subjected to electrophoresis on $1 \%$ agarose gel, $1 \times \mathrm{TBE}$ at $120 \mathrm{~V}$ for 90 minutes, stained with SYBR ${ }^{\circledR}$ Safe DNA gel stain and observed under UV light. All samples with visible DNA bands ranging from 800 to $1000 \mathrm{bp}$ were sequenced (Macrogen, The Netherlands) utilizing both ITS 4 and ITS 6 universal Phytophthora primers. Sequences were analyzed using DNA Dynamo and compared against accessions in the online Phytophthora database (http://www.phytophthoradb.org/; [24]). Sequences were aligned using MEGA 7, and the ClustalW Multiple alignment tool, as implemented in MEGA 7 [25]. Phylogenetic trees were constructed using the maximum likelihood method implemented in MEGA 7, with 1000 bootstrap replicates. In addition to sequences obtained in this research, several sequences available on http://www.phytophthoradb.org/ were utilized to compare our sequences with other available Phytophthora spp. sequences.

Pathogenicity test. For the pathogenicity test, material from dormant one year old chestnut shoots taken from a single coppice was used [26]. The chestnut shoots (length $10-15 \mathrm{~cm}$; width $5-15 \mathrm{~mm}$ ) were inoculated by removing a small piece of bark and insertion of agar plugs (ca $3 \times 3 \mathrm{~mm}$ ) extracted from a fresh culture of $P$. cactorum. Inoculation points were covered with sterile moist cotton plugs and secured with Parafilm. Two isolates were used for inoculations; one isolated from a chestnut, the other one from an apple tree. Forty replicate inoculations were made per isolate, 20 were on $5-10 \mathrm{~mm}$ diam. shoots, 20 on $10-15 \mathrm{~mm}$ diam. shoots. Inoculated shoots were placed on sterile moist filter papers in $15 \mathrm{~cm}$ diam. glass Petri dishes, with 10 replicate shoots per Petri dish, and incubated in dark for 7 days at room temperature $\left(24{ }^{\circ} \mathrm{C} \pm 4{ }^{\circ} \mathrm{C}\right.$; Figure 1 ), after which lesion lengths were measured. Ten random samples were taken for re-isolation on selective PARPNH medium to prove that the Phytophthora isolates caused the lesions. 


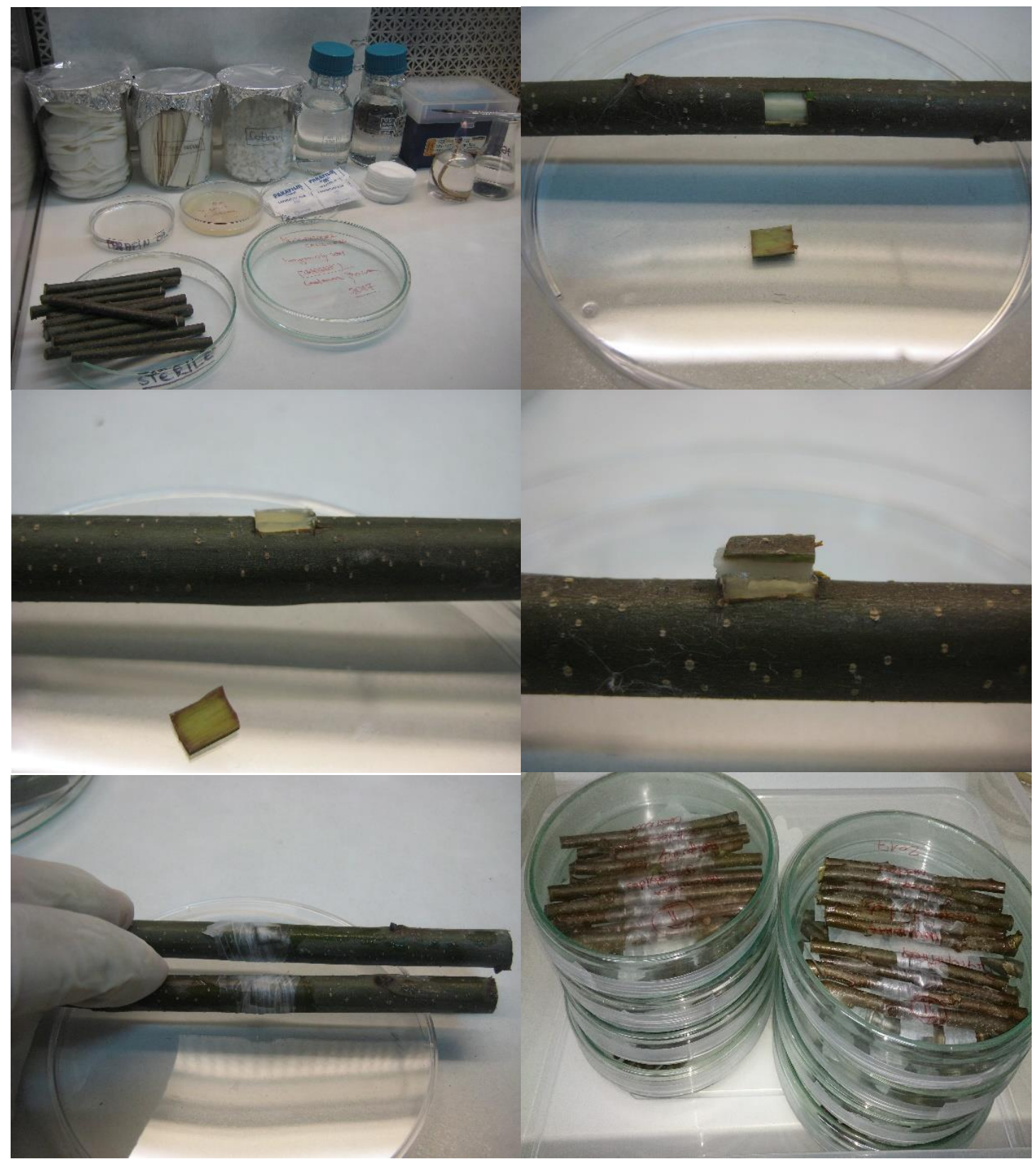

Figure 1. Inoculation of chestnut twigs for pathogenicity tests

\section{RESULTS AND DISCUSSION}

Eighty-one soil, root and/or bark samples were collected from apple trees which exhibited disease symptoms characteristic of Phytophthora infection in 16 apple orchards. In addition, 54 soil, root and/or bark samples were collected from symptomatic chestnut trees from 11 sites. Of these, fifty cultures with morphologies resembling Phytophthora spp. were obtained on selective media. Twenty-one isolates were identified as $P$. cactorum by culture morphology and microscopic features. Of these 19 isolates, 16 were from apple trees, and 3 from chestnut trees. All isolates were with coralloid culture morphology (Figure 2) and an average daily growth rate of $6.5 \mathrm{~mm}$ when incubated at room temperature (24 ${ }^{\circ} \mathrm{C} \pm 4{ }^{\circ} \mathrm{C}$ ) in the dark on V8 agar. Oogonia measured $29 \times 27 \mu \mathrm{m}$ on average, whereas oospores measured $21 \times 21 \mu \mathrm{m}$ on average. Antheridia were $13 \times 11 \mu \mathrm{m}$. The mean zoosporangia dimensions were $45 \times 35$ $\mu \mathrm{m}$; chlamydospores were rare but measured $22 \times 21$ $\mu \mathrm{m}$ on average (Figure 3 ).

All Phytophthora spp. isolates obtained from apple and chestnut trees in Macedonia clustered together on the same branch of the phylogenetic tree as $P$. cactorum, $P$. hedraiandra and $P$. pseudotsugae. While the aforementioned species are highly similar and poorly resolved between themselves, the whole branch is highly supported with a bootstrap value of 91 (Figure 4). 

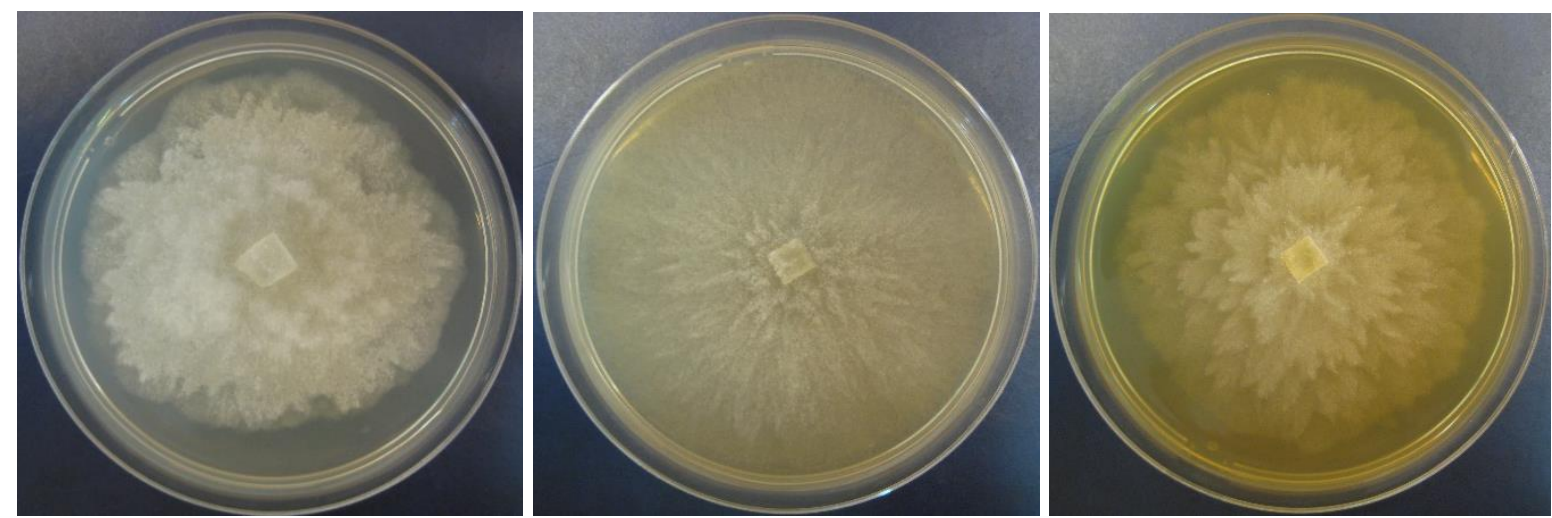

Figure 2. Characteristic coralloid morphology of P. cactorum on (left to right) PDA, V8 Agar and MEA

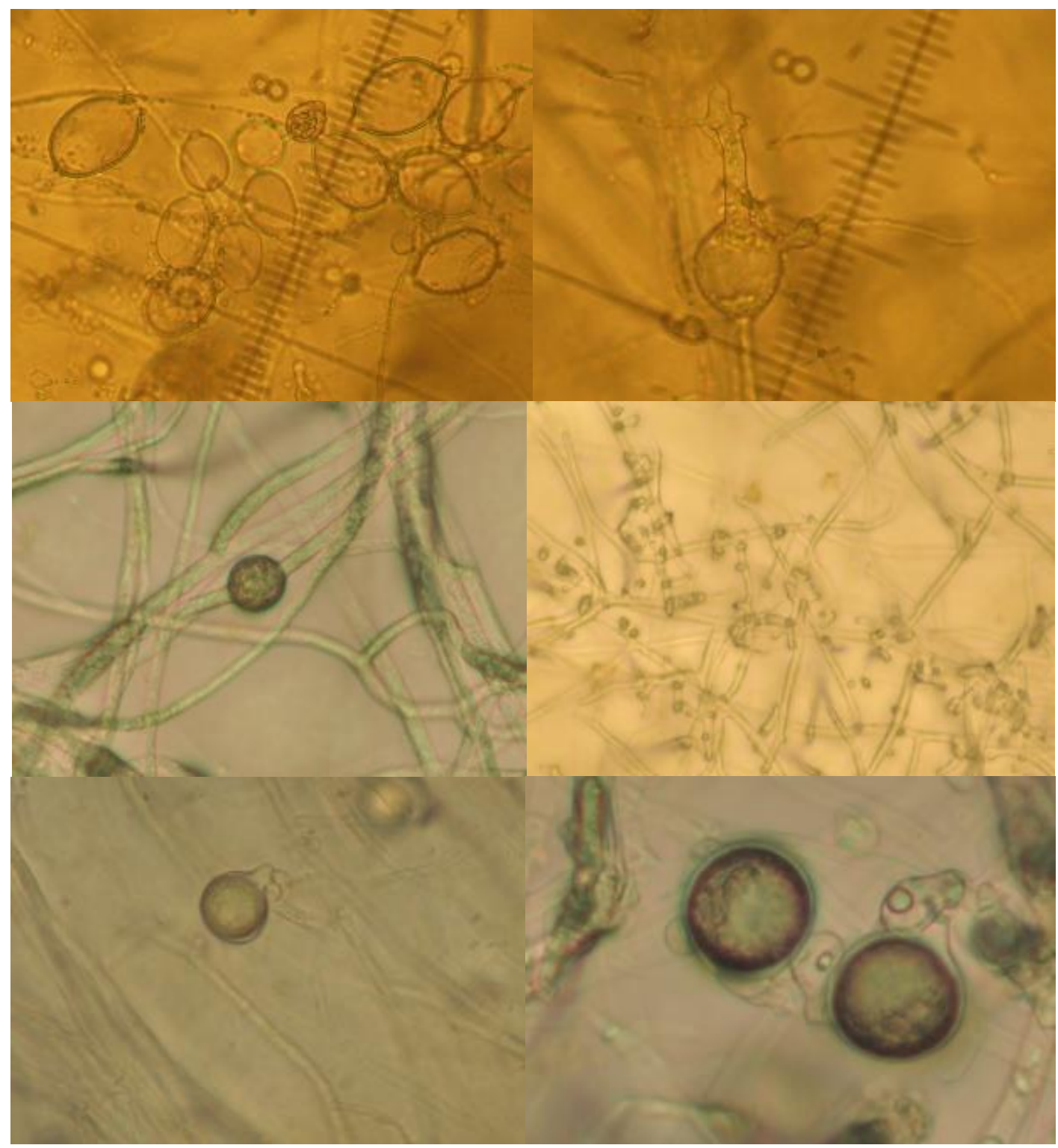

Figure 3. Reproductive structures of $P$. cactorum: typical formation of zoosporangia in groups (upper left); characteristic oospore proliferation in sporangium (upper right), chlamydospore (middle left), hyphal swellings (middle right), oospore (down left) and oogonia with paragenic antheridium (down right). 


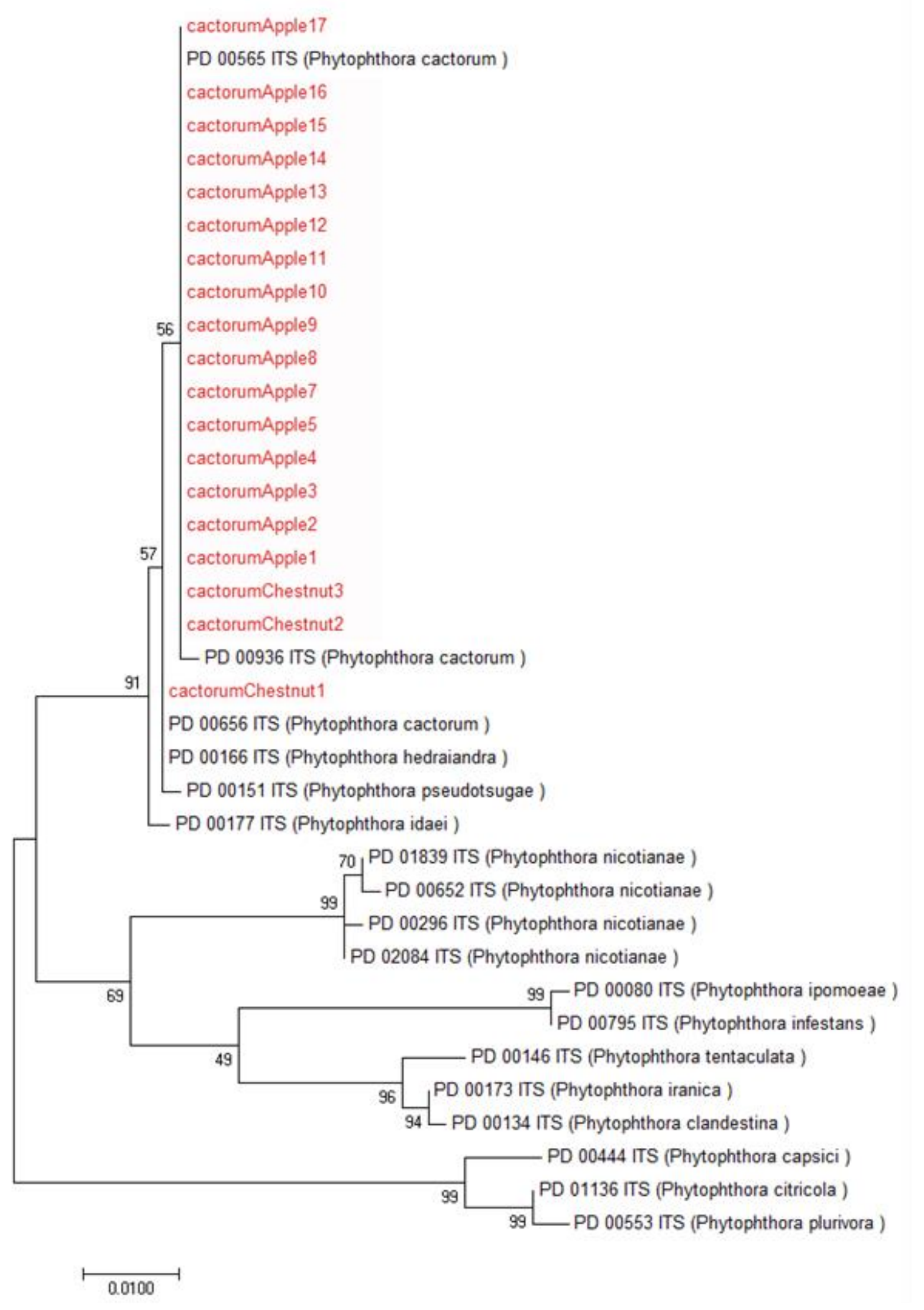

Figure 4. Phylogenetic tree constructed using MEGA7, using maximum likelihood method and Tamura-Nei substitution model. Bootstrap values were obtained after 1000 pseudereplicates. Isolates characterized in this study are in red, while the ITS sequences, publicly available at http://www.phytophthoradb.org are in black. 
Nevertheless, most sequences from Macedonia were highly similar, indicating a single Phytophthora sp. was responsible for the infections in both apple orchards and chestnut forests. No differences in morphologies of cultures and the dimensions of the reproductive structures were observed between the isolates of $P$. cactorum originating from the two different host plant species. The pathogenic- ity tests also showed no difference between the length of the lesions on the chestnut twigs induced by the isolates originating from the two different host plant species. Lesion lengths ranged from 22 $\mathrm{mm}$ to $59 \mathrm{~mm}$ on the $5-10 \mathrm{~mm}$ diam. shoots, and between $30 \mathrm{~mm}$ and $59 \mathrm{~mm}$ on shoots $10-15 \mathrm{~mm}$ in diam. (Table 2; Figure 5, 6).

Table 2. Lengths of the lesions on chestnut twigs, induced by inoculation of $P$. cactorum isolates originating from the 2 plant host species

\begin{tabular}{|c|c|c|c|}
\hline \multirow[t]{2}{*}{ Number } & \multirow{2}{*}{$\begin{array}{l}\text { Shoot diameter } \\
(\mathrm{mm})\end{array}$} & \multicolumn{2}{|c|}{$\begin{array}{l}\text { Dimensions of emerged lesions according to } \\
\text { Phytophthora isolates (mm) }\end{array}$} \\
\hline & & P. cactorum (chestnut) & P. cactorum (apple) \\
\hline 1 & \multirow{20}{*}{$5-10$} & 49 & 57 \\
\hline 2 & & 32 & 49 \\
\hline 3 & & 34 & 41 \\
\hline 4 & & 39 & 47 \\
\hline 5 & & 38 & 40 \\
\hline 6 & & 51 & 29 \\
\hline 7 & & 31 & 34 \\
\hline 8 & & 47 & 47 \\
\hline 9 & & 41 & 51 \\
\hline 10 & & 32 & 39 \\
\hline 11 & & 34 & 42 \\
\hline 12 & & 39 & 46 \\
\hline 13 & & 30 & 49 \\
\hline 14 & & 47 & 50 \\
\hline 15 & & 50 & 40 \\
\hline 16 & & 32 & 59 \\
\hline 17 & & 52 & 36 \\
\hline 18 & & 33 & 32 \\
\hline 19 & & 41 & 22 \\
\hline 20 & & 49 & 31 \\
\hline 1 & \multirow{20}{*}{$10-15$} & 0 & 39 \\
\hline 2 & & 37 & 35 \\
\hline 3 & & 31 & 44 \\
\hline 4 & & 41 & 49 \\
\hline 5 & & 38 & 33 \\
\hline 6 & & 38 & 39 \\
\hline 7 & & 30 & 33 \\
\hline 8 & & 33 & 49 \\
\hline 9 & & 42 & 38 \\
\hline 10 & & 35 & 47 \\
\hline 11 & & 36 & 53 \\
\hline 12 & & 41 & 30 \\
\hline 13 & & 39 & 39 \\
\hline 14 & & 51 & 59 \\
\hline 15 & & 51 & 55 \\
\hline 16 & & 34 & 41 \\
\hline 17 & & 36 & 41 \\
\hline 18 & & 47 & 40 \\
\hline 19 & & 33 & 31 \\
\hline 20 & & 42 & 35 \\
\hline
\end{tabular}


These results further support the conclusion that Phytophthora isolates from Macedonia had similar growth rates and pathogenicity on chestnut, and were most likely $P$. cactorum, or at least within this species complex.

Regarding other countries in the region, $P$. cactorum has been reported as pathogen on peach, almond, apple and strawberry [27, 28] as well as from cherry [29, 30], all in Greece. Regarding pathogenicity, isolates originating from peach and almond trees were more aggressive than apple and strawberry isolates [31]. In Bulgaria, P. cactorum has been reported on American ginseng [32], and on apple and cherry [33]. The pathogenicity of $P$. cac- torum has been assessed on young apple trees and apple fruits [33]. In Serbia P. cactorum has been reported on maple [34], in the soils of young hybrid poplar stands [35], on sycamore, walnut, common hawthorn, sessile oak, Hungarian oak, common alder, European wild pear and apple [36]. Having in mind these findings and the generally accepted view of $P$. cactorum as a generalist pathogen, we would expect that this plant pathogen is present on numerous other plant hosts in Macedonia. Further research is needed in order to gain important data on plant hosts, as well as diversity and pathogenicity of $P$. cactorum in the country.

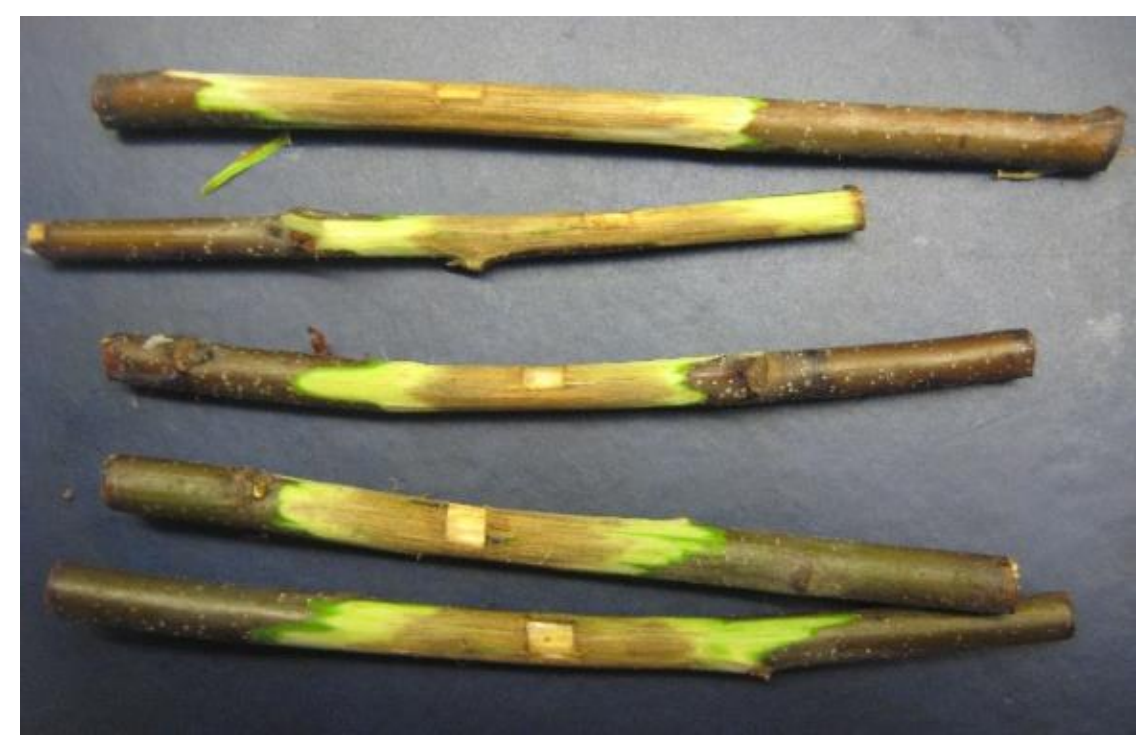

Figure 5. Lesions emerged after inoculation of chestnut twigs with P. cactorum

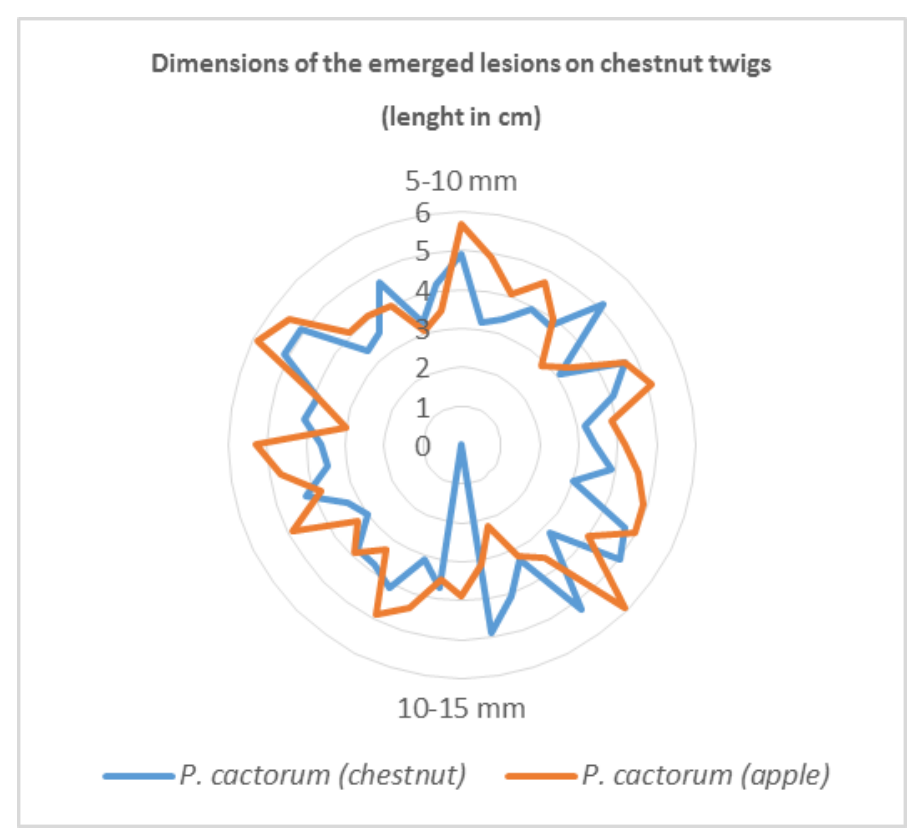

Figure 6. Dimensions of the emerged lesions on chestnut twigs 
Acknowledgments. SCOPES Joint Research Project "Invasive chestnut diseases in the Balkans and Georgia - epidemiological research and management options". Multilateral project (Switzerland, Croatia, Macedonia and Georgia), 2013-2016 (IZ73Z0_152525).

SEE-ERA.NET PLUS Joint Research Project "Diversity and invading Phytophthora spp. plant pathogens in agro and forest ecosystems in Southeast Europe". Multilateral project (Bulgaria, Macedonia, Greece, Serbia and Romania), 2010-2012.

COST (Cost Action FP0801: Established and Emerging Phytophthora: Increasing Threats to Woodland and Forest Ecosystems.)

\section{REFERENCES}

[1] K. Yoshida et al., The rise and fall of the Phytophthora infestans lineage that triggered the Irish potato famine. Elife 2 (2013), pp. e00731.

[2] D. Erwin, O. Ribeiro. (APS Press), 1996), pp.

[3] G. Waterhouse, J. Waterston, Phytophthora cactorum. CMI Descriptions of pathogenic fungi and bacteria, (1966), pp. 2.

[4] T. Jung, H. Blaschke, P. Neumann, Isolation, identification and pathogenicity of Phytophthora species from declining oak stands. European Journal of Forest Pathology 26 (1996), pp. 253272.

[5] J. Hantula, A. Lilja, H. Nuorteva, P. Parikka, S. Werres, Pathogenicity, morphology and genetic variation of Phytophthora cactorum from strawberry, apple, rhododendron, and silver birch. Mycological Research 104 (2000), pp. 1062-1068.

[6] A. Vettraino, G. Natili, N. Anselmi, A. Vannini, Recovery and pathogenicity of Phytophthora species associated with a resurgence of ink disease in Castanea sativa in Italy. Plant Pathology 50 (2001), pp. 90-96.

[7] e. link, https://gd.eppo.int/taxon/PHYTCR/distribution/MK.

[8] G. M. Waterhouse, Key to the species of Phytophthora de Barry. (Commonwealth Mycological Institute; England, 1963).

[9] D. J. Stamps, G. M. Waterhouse, F. J. Newhook, G. S. Hall, Revised tabular key to the species of Phytophthora. Mycological papers, CAB International, Wallingford Oxon 162 (1990), pp. 1-28.

[10] L. Leonian, Identification of Phytophthora species. West Virginia Agriculture Experiment Station Bulletin. 262 (1934), pp. 2-36.

[11] P. Oudemans, M. D. Coffey, A revised systematics of twelve papillate Phytophthora species based on isozyme analysis. Mycological Research 95 (1991), pp. 1025-1046.

[12] H. Förster, M. D. Coffey, Approaches to the taxonomy of Phytophthora using polymorphisms in mitochondrial and nuclear DNA. Phytophthora, (1991), pp. 164-183.

[13] C. Brasier, Phytophthora biodiversity: how many Phytophthora species are there. Phytophthoras in Forests and Natural Ecosystems (eds.: EM Goheen, SJ Frankel). Albany, USDA Forest Service. General Technical Report, PSW-GTR-221, (2009), pp. 101115.

[14] J. Nechwatal et al., The morphology, behaviour and molecular phylogeny of Phytophthora taxon Salixsoil and its redesignation as Phytophthora lacustris sp. nov. Plant Pathology, (2012), pp. 355-369.

[15] L. P. N. M. Kroon, H. Brouwer, A. W. A. M. de Cock, F. Govers, The genus Phytophthora anno 2012. Phytopathology 102 (2012), pp. 348-364.

[16] F. N. Martin, J. E. Blair, M. D. Coffey, A combined mitochondrial and nuclear multilocus phylogeny of the genus Phytophthora. Fungal Genetics and Biology 66 (2014), pp. 19-32.

[17] L. P. N. M. Kroon, F. T. Bakker, G. B. M. van den Bosch, P. J. M. Bonants, W. G. Flier, Phylogenetic analysis of Phytophthora species based on mitochondrial and nuclear DNA sequences. Fungal Genetics and Biology 41 (2004), pp. 766-782.

[18] T. Jung, H. Blaschke, Phytophthora root rot in declining forest trees. PHYTON-HORN- 36 (1996), pp. 95-102.

[19] T. Jung, H. Blaschke, W. Oßwald, Involvement of soilborne Phytophthora species in Central European oak decline and the effect of site factors on the disease. Plant Pathology 49 (2000), pp. 706-718.

[20] T. Jung, T. I. Burgess, Re-evaluation of Phytophthora citricola isolates from multiple woody hosts in Europe and North America reveals a new species, Phytophthora plurivora sp. nov. Persoonia - Molecular Phylogeny and Evolution of Fungi 22 (2009), pp. 95-110.

[21] P. J. Ann, W. H. Ko, Growth Rate and Colony Morphology of Progenies of Zoospores and Selfed Oospores of Phytophthora parasitica. Mycologia 82 (1990), pp. 693-697.

[22] T. White, T. d. Bruns, S. Lee, Amplification and direct sequencing of fungal ribosomal RNA genes for phylogenetics. PCR protocols: a guide to methods and applications. Eds., MA Innis, DH Gelfand, JJ Sninsky, and TJ White. Academic Press, New York, (1990), pp. 315-322.

[23] D. Cooke, J. Duncan, N. Williams, M. Weerdt, P. Bonants, Identification of Phytophthora species on the basis of restriction enzyme fragment analysis of the internal transcribed spacer regions of ribosomal RNA. EPPO Bulletin 30 (2000), pp. 519-523.

[24] Z. Zhang, S. Schwartz, L. Wagner, W. Miller, A greedy algorithm for aligning DNA sequences. Journal of Computational biology 7 (2000), pp. 203-214. 
[25] S. Kumar, M. Nei, J. Dudley, K. Tamura, MEGA: a biologist-centric software for evolutionary analysis of DNA and protein sequences. Briefings in bioinformatics 9 (2008), pp. 299-306.

[26] T. Jung, J. Nechwatal, Phytophthora gallica sp. nov., a new species from rhizosphere soil of declining oak and reed stands in France and Germany. Mycological Research 112 (2008), pp. 1195-1205.

[27] T. Thomidis, Variability in pathogenicity among Greek isolates of Phytophthora cactorum to four peach rootstocks. Australian journal of experimental agriculture 43 (2003), pp. 99-103.

[28] T. Thomidis, Seasonal variation in crown rot of GF677 and KID I peach rootstocks by Phytophthora cactorum, P. citrophthora and P. syringae. Phytopathologia Mediterranea 39 (2000), pp. 396-403.

[29] T. Thomidis, T. Sotiropoulos, Pathogenicity of 11 Phytophthora species on CAB-6P cherry rootstock. (2003).

[30] T. Thomidis, I. Karayiannis, C. Tsipouridis, Susceptibility of thirty cherry genotypes on Phytophthora cactorum, P. citrophthora, P. citricola and P. parasitica. Journal of phytopathology 156 (2008), pp. 446-451.
[31] T. Thomidis, Testing variability in pathogenicity ofPhytophthora cactorum, P. citrophthora andP. syringae to apple, pear, peach, cherry and plum rootstocks. Phytoparasitica 29 (2001), pp. 47.

[32] S. Bobev, S. Baeyen, C. Crepel, M. Maes, First report of Phytophthora cactorum on American ginseng (Panax quinquefolius) in Bulgaria. Plant Disease 87 (2003), pp. 752-752.

[33] M. Nakova, Phytophthora root and crown rot on apples in Bulgaria. Pesticidi $i$ fitomedicina $\mathbf{2 5}$ (2010), pp. 43-50.

[34] I. Milenković et al., Morphological and molecular identification of Phytophthora species from maple trees in Serbia. Genetika 46 (2014), pp. 353-368.

[35] N. Keča, I. Milenković, L. Keča, Mycological complex of poplars in Serbia. J. FOR. SCI 61 (2015), pp. 169-174.

[36] I. Milenković, Diversity of species from the Phytophthora genus and their role in the decline of broadleaved forest trees in serbia. University of Belgrade, Faculty of Forestry, 17-07-2015, (2015).

[37] G. Filipovski et al., Soil Maps of the Republic of Macedonia. Agricultural institute - Ss. Cyril and Methodius University, Skopje, (2015).

\title{
PHYTOPHTHORA CACTORUM (LEBERT \& COHN) J. SCHRÖT, ПРИЧИНИTEЛ НА СУШЕЊЕ НА КОСТЕНОВИ И ЈАБОЛКОВИ ДРВЈА ВО МАКЕДОНИЈА
}

\author{
Михајло Ристески ${ }^{1}$, Stephen Woodward ${ }^{2}$, Marin Ježić ${ }^{3}$, Раде Русевски ${ }^{4}$, \\ Билјана Кузмановска ${ }^{4}$, Кирил Сотировски ${ }^{1}$
}

\author{
${ }^{1}$ Шумарски факултет, Универзитет „Св. Кирил и Методиј“, Скопје, Република Македонија \\ ${ }^{2}$ The Institute of Biological and Environmental Sciences, University of Aberdeen, Scotland \\ ${ }^{3}$ Faculty of Science, University of Zagreb, Croatia \\ ${ }^{2}$ Факултет за земјоделски науки и храна,, Универзитет „Св. Кирил и Методиј“, \\ Скопје, Република Македонија
}

Во периодот од 2013-2017 г., во Република Македонија беше истражувана здравствената состојба на 11 костенови популации и 16 јаболкови овоштарници/насади. Од нив беа колектирани почвени, коренови и примероци од кора од стебла кои покажуваа симптоми кои се сметаат типични за Phytophthora. Користејќи ливчиња од Prunus laurocerasus како мамки и селективна подлога V8 Агар (PARPNH), изолиравме 19 чисти култури на Phytophthora sp. кои беа идентификувани како P. cactorum преку секвенционирање на ITS регионот. Шестнаесет изолати потекнуваа од јаболкници, а 3 беа од костенови стебла. Филогенетските анализи покажаа мала разлика меѓу изолатите на $P$. cactorum кои потекнуваат од костенови стебла споредено со оние од јаболкови насади. Од проценката на патогеноста со користење на костенови гранчиња не се покажаа разлики меѓу изолатите на P. cactorum кои потекнуваа од различни видови растенија-домаќини.

Клучни зборови: Malus spp.; Castanea sativa; патогеност; филогенетски анализи 
